Please do not remove this page

RMIT

UNIVERSITY

\title{
Changes in higher education and valuing the job: the views of accounting academics in Australia
}

Watty, Kim; Bellamy, Sheila; Morley, Clive

https://researchrepository.rmit.edu.au/esploro/outputs/9921863529601341/filesAndLinks?institution=61RMIT_INST\&index=null

Watty, K., Bellamy, S., \& Morley, C. (2008). Changes in higher education and valuing the job: the views of accounting academics in Australia. Journal of Higher Education Policy and Management, 30(2), 139-151. https://doi.org/10.1080/13600800801938747

Document Version: Accepted Manuscript

Published Version: https://doi.org/10.1080/13600800801938747

Repository homepage: https://researchrepository.rmit.edu.au (C) 2008 Association for Tertiary Education Management and the Downloaded On 2023/04/27 00:18:36 +1000 
$\mathbf{T}$

\section{Changes in Higher Education and Valuing the Job: The Views of Accounting Academics in Australia}

KIM WATTY, SHEILA BELLAMY \& CLIVE MORLEY, RMIT University, Australia

\section{Citation:}

Watty, K, Bellamy, S and Morley, C 2008, 'Changes in higher education and valuing the job: The views of accounting academics in Australia', J ournal of Higher Education Policy and Management, vol. 30, no. 2, pp. 139-151.

Correspondence: Dr Kim Watty, Director of Teaching Quality, School of Accounting and Law, RMIT University, GPO Box 2476V, Melbourne, Victoria 3001, Australia. Tel: + 613 9925 1606; fax: + 6139925 5741; email: kim.watty@rmit.edu.au 


\title{
Changes in Higher Education and Valuing the Job: The Views of Accounting Academics in Australia
}

\begin{abstract}
In a previous article (Watty, Bellamy and Morley 2003) the authors reported on survey research that investigated reasons why academics from business disciplines enter and remain in academia, and the conditions they deem necessary to creating ideal work satisfaction. For both entering and remaining, as well as in achieving ideal work satisfaction, the most important factors were found to be autonomy and flexibility, with teaching and research the next most important factors. In a subsequent analysis of the data, reported in this article, the authors identify and explore significant differences between accounting academics and other business academics in the relative importance placed on these key factors.

The findings may be used to inform policy-makers and university administrators of the importance of discipline differences when identifying key factors for recruitment and retention of accounting academics specifically, and business academics generally.
\end{abstract}

Keywords: Accounting academics, employment, work satisfaction, retention. 


\section{Introduction}

This research was prompted by the seeming paradox that, while the working conditions of Australian academics have worsened in recent years and job satisfaction has decreased commensurately, there is little evidence of academics leaving the sector in greater numbers than in the past. To investigate this issue, the authors undertook survey research of over 3000 business academics employed at Australian universities. The term 'business academics' is used to refer to academics working in business, commerce, accounting, management and economics faculties, and similar divisions of Australian universities.

The purpose of the study was to discover the relative importance that business academics attach to a range of factors in deciding whether to become an academic and whether to remain an academic, as well as to identify the conditions conducive to the achievement of ideal work satisfaction. It was anticipated that answers to these questions would allow inferences to be made about why academics are remaining in academia despite the changing nature of academic work and of working conditions.

The initial findings, reported in Watty, Bellamy and Morley (2003), revealed that, overwhelmingly, the primary reasons for respondents both becoming academics and remaining academics were autonomy and flexibility in their workplace. Teaching and research were the two next most important factors-however, both were far outweighed in their level of importance by autonomy and flexibility. The fifth most important factor in becoming and remaining an academic was being part of a community of scholars. These results highlight the level of importance that business academics attach to how they undertake their activities-in an autonomous and flexible manner - as opposed to what they do as academics - that is, teach and engage in research. The fifth factor, membership of a community of scholars, goes to the heart of what it is to be an academic.

Given the changing landscape of higher education (HE) in Australia, reflected in increasing levels of accountability and control resulting from structural and systemic changes, further analysis was undertaken to see whether there were any significant differences at the level of discipline with respect to the importance of these factors. In this analysis the authors focused on the largest sub-group of business academics-namely, accountants. Of all survey respondents, approximately 50\% were from the accounting, economics and finance disciplines. 
The breakdown was: accounting (21\%); economics (20\%); finance (9\%); information technology (6\%); business law (7\%); marketing (12\%); management (15\%); industrial relations (2\%); quantitative methods/econometrics (4\%); and other (4\%).

The research question addressed in this study is: how can academics from a particular discipline, such as accounting, be distinguished from other business academics on the basis of their reasons for becoming an academic? Similar questions are posed in terms of the reasons for remaining an academic and their ideal requirements for work satisfaction.

The analysis revealed some significant differences in the relative importance that accounting academics and other business academics place on autonomy and research in becoming academics, on teaching and administration in remaining academics, and on intellectual atmosphere in achieving ideal work satisfaction.

The remainder of the paper is structured as follows: first, on overview of prior research about changes in the management of HE institutions is presented with a focus on the impact of these changes on autonomy and accountability for academics in general; a description of the research method and findings are then presented. The paper concludes with consideration of the implications of the findings for policy-makers and university administrators.

\section{New Public Management}

Macro and micro assessment of performance and a focus on accountability at the institutional level has dominated the activities of management in HE over the past two decades and continues to do so. Reflecting this has been a move to a more corporate form of university management. New Public Management (NPM) and Managerialism have been the two labels most widely-assigned in the literature to describe this new approach, transported from the private sector to the public sector, including higher education. The assumption is that the private sector is more efficient than the public sector and that the application of commercial models of management by higher education institutions will improve standards, without the need to increase spending (Erridge et al. 1999). Whether the importation of private sector management techniques are appropriate is a contentious issue. A number of authors suggest that their simple application is not always appropriate, claiming that in public sector institutions goals are ambiguous, outputs not readily identifiable, and there is a need for independence and autonomy to carry out professional activities (Groot, 1999). While the need 
for public accountability is logical, the problem in the public sector is that goals and objectives are primarily social and political, rather than the economic (monetary) goals that dominate in the private sector (Coy and Pratt, 1998).

Clearly, the emergence of NPM impacts the degree of autonomy, flexibility and accountability that academics exercise in their daily working lives. As indicated by previous research (Watty, Bellamy and Morley 2003) these two factors were those rated most important by business academics as to why they became, and why they remain an academic. Given these findings, the consequences of NPM in the university sector may take on increased significance.

\section{Accountability and Autonomy}

Ackroyd and Ackroyd (1999) researched problems associated with assuming that greater accountability is linked to improved performance in universities and concluded that calls for greater accountability, as a panacea for improved performance, is a general prescription that ignores differences in the types of problems being experienced. More appropriate prescriptions for reform should be linked to specific problems identified and not simply added to increasing layers of accountability.

What are the perceptions of academics on changing accountability requirements? In a study of Australia’s higher education ‘quality’ policy process between 1992 and 1995, Vidovich (1998) collected data at 4 levels of a policy trajectory used as the analytical framework. At the micro level of analysis she categorised 2 groupings: (1) the micro level representing institutional managers; and (2) the mini-micro level representing grassroots academics - that is, academics clustered around disciplines in schools or departments. This separation at the micro level reflected an increasing gap between the perspectives of managers and those of academics. Vidovich found that respondents at the mini-micro level (grassroots academics) reported having experienced dramatic changes in accountability requirements. A large majority (91\%) of academics had experienced increasing growth in the requirements for accountabilityprimarily to government (46\%) and institutional managers (35\%). Ninety-five percent of respondents indicated that increased accountability had led to 'top-down' decision-making

processes and structures, while a large majority identified decreased individual and institutional autonomy. 
Interestingly, in the Vidovich study (1998), 69\% of respondents had observed varying levels of resistance among academics to increased accountability demands; these ranged from verbal objections (37\%) to outright refusal (33\%), careless responses (21\%) and delaying tactics (9\%). The finding that academics are not passive recipients of change and adjust their behaviours appropriately are consistent with those of studies by Trowler (1998) and Newton (2000), but contrary to research undertaken by McMurty (1991), who observed that academics behave in a conformist manner, mutely accepting changes imposed upon them.

In their research into the quality of academic working lives in a large comprehensive institution in Australia in 1997, Winter et al. (2000) surveyed over 300 full-time academics —of which $23 \%$ were from business disciplines - seeking information about respondents' perceptions of their prevailing work environment and work attitudes. The 5 work environment domains were:

- Role stress characteristics (role ambiguity, conflict, overload)

- Job characteristics (job challenge, autonomy, skill variety, task identity, feedback)

- Supervisory characteristics (consideration/supportive supervision)

- Structural characteristics (centralisation, formalisation of changing structure of universities)

- Sectoral characteristics (large scale change, increased competition, academic entrepreneurialism) (Winter et al. 2000, p. 283).

Two aspects of the findings in relation to the Job Characteristics domain are of particular relevance to the present study. First, that "positive job characteristics and role clarity suggest that the core tasks of teaching and research remain major motivating aspects of academic work" (Winter et al. 2000, p. 287). This finding is consistent with the initial findings from the present study, except to the extent that autonomy and flexibility factors far outweigh the core tasks in explaining why academics enter and remain in academia (Watty, Bellamy and Morley 2003).

Second, and to the researchers' surprise, respondents overall strongly agreed that their jobs were characterised by high levels of autonomy, and that this was a positive aspect of the quality of academic life. It is interesting to speculate on why their perceptions were that they enjoyed high levels of autonomy, yet at the same time acknowledged increasing pressures associated with the changing academic role. Perhaps one explanation is to be found in the 5 
year gap between the collection of data for the research undertaken by Winter et al. in 1997 and the current research, where data was collected in 2002. Those academics currently working in the system would appreciate the extent of change in their working conditions over that 5 year period. Winter et al. (2000) also found that professors reported higher perceived levels of sectoral change than did associate lecturers. This finding supports the conclusion from the original findings of this study: that academics at the local level may be able to isolate themselves to some extent from the mega-structural and political changes occurring at more senior levels in the system. It also lends support to the growing body of informed opinion and evidence in the literature that suggests a gap between professional administrators and academics, with academic distrust of administrations that are viewed as having an increasing desire to conceive higher education as a corporate service industry acting as a government funded provider of services to students (Watty, Bellamy and Morley 2003; Taylor et al. 1998). Traditionally, the nature of academic work has been characterised by high levels of professional autonomy, self-management and control over individually selected (usually preferred) tasks. The nature of academic work-particularly in the university sector of the Australian binary system up until the late eighties - reflected a culture of individualism in both research and teaching. However, Anderson et al (2002, p. 54) found that academics are losing autonomy over the very area of their expertise.

In a 1999 Australian study by McInnes of over 1,500 academics, including 180 from business disciplines, the author concluded that the level of commitment remains high in the profession, with a sizeable majority indicating that they are motivated by intrinsic interests rather than by material rewards (extrinsic interests) in the work they do. Further, Coaldrake and Stedman (1998) report that academics perceive their current work roles as: more stressful; more demanding; more centrally-directed; less autonomous; less satisfying; less motivating; and less rewarding. Although academics may be motivated more by intrinsic factors-such as intellectual challenge, interaction with students, autonomy and flexibility-than by extrinsic factors — such as salary, workload and opportunities - there has been an erosion in the former as well as the latter (Watty, Bellamy and Morley 1999).

How has autonomy for academics been eroded? Dearlove (1997, p. 62) observes that mass higher education in the UK has reduced academic control over student entry, vocationalism has 
seen the introduction of skills teaching into the curriculum, timetables are dictated by space constraints, professional administrators take a keen interest in productivity and quality against a backdrop of funding and regulatory constraint, student consumers are more demanding, student evaluations can feed into promotion prospects, there is an emphasis on student-centred learning, and teaching-oriented academics are being required to undertake research and secure research grants. The list goes on...

\section{Present Study}

The objective of the original study (Watty, Bellamy and Morley 2003) was to identify business academics' perceptions about the relative importance of various factors in explaining why they became an academic, why they remain an academic, and the conditions conducive to the achievement of ideal work satisfaction. The further analysis undertaken and reported in this article investigates the important factors identified in the original analysis and to determine and explain any significant differences at the level of discipline, with a focus on accounting.

\section{Research Method}

Data were collected by means of a postal survey. Some 3,161 questionnaires were distributed to business academics, with a response rate of 42 per cent (1,328 questionnaires). Contact details were obtained from university websites, since there was no single, up to date database recording such details for Business staff at all levels and in all Australian universities. The demographics are shown in Table 1, with a breakdown between accountants and other business academics.

\section{Data Analysis}

Table 1 shows basic descriptive data on the sample, comparing accounting academics with other business academics. The two match quite closely, although the accountants tend to have been in academia longer. 
TABLE 1. Demographics: Accountants and other Business academics

\begin{tabular}{|c|c|c|}
\hline & $\begin{array}{c}\text { Non-accountants } \\
\%\end{array}$ & $\begin{array}{c}\text { Accountants } \\
\%\end{array}$ \\
\hline \multicolumn{3}{|l|}{ Gender } \\
\hline Male & 68 & 69 \\
\hline Female & 32 & 31 \\
\hline Total & 100 & 100 \\
\hline Sample Size & 970 & 257 \\
\hline \multicolumn{3}{|l|}{ Current position } \\
\hline Lecturer A & 10 & 12 \\
\hline Lecturer B & 38 & 42 \\
\hline Lecturer C & 26 & 25 \\
\hline Lecturer D & 12 & 8 \\
\hline Lecturer E & 11 & 11 \\
\hline Other & 3 & 2 \\
\hline Total & 100 & 100 \\
\hline Sample Size & 995 & 260 \\
\hline \multicolumn{3}{|l|}{ Employment status } \\
\hline Continuing & 75 & 73 \\
\hline Contract & 25 & 27 \\
\hline Total & 100 & 100 \\
\hline Sample Size & 597 & 161 \\
\hline \multicolumn{3}{|l|}{$\begin{array}{l}\text { Length of academic } \\
\text { employment }\end{array}$} \\
\hline$<1$ year & 2 & 2 \\
\hline $1-4$ years & 17 & 8 \\
\hline $5-7$ & 15 & 9 \\
\hline $8-20$ & 43 & 58 \\
\hline $21+$ & 23 & 24 \\
\hline Total & 100 & 100 \\
\hline Sample Size & 1002 & 262 \\
\hline
\end{tabular}

In the questionnaire, respondents were presented with a list of 13 factors representing possible explanations of why they became and why they remain an academic. They were asked to rate each of these on a five point scale, ranging from Very Unimportant (1) to Very Important (5). Table 2 shows a comparison of these factors. The importance placed on the various reasons for becoming and remaining an academic were very consistent. Flexibility, Autonomy, Teaching, Research and being part of a Community of Scholars were rated Important or Very Important by a clear majority of business academics. Job security, Community service, Status, Leadership opportunities, Total income and University salary were important for a significant minority of business academics. Poor job prospects outside academia and Administration were important to few business academics. 
TABLE 2. Factors importance in becoming and remaining an academic:

mean scores*

\begin{tabular}{|lcc|cc|}
\hline Factor & $\begin{array}{c}\text { Non-accountants } \\
\text { Becoming }\end{array}$ & Remaining & $\frac{\text { Accountants }}{\text { Becoming }}$ & $\begin{array}{c}\text { Remainin } \\
\text { g }\end{array}$ \\
\hline Flexibility & 4.43 & 4.38 & 4.35 & 4.26 \\
\hline Autonomy & 4.31 & 4.25 & 4.05 & 4.05 \\
\hline Teaching & 3.84 & 3.62 & 4.05 & 3.85 \\
\hline Research & 3.82 & 3.80 & 3.40 & 3.59 \\
\hline Community of scholars & 3.77 & 3.63 & 3.54 & 3.45 \\
\hline & & & & \\
\hline Community service & 2.86 & 2.80 & 2.88 & 2.86 \\
\hline Job security in academia & 2.82 & 2.85 & 2.86 & 2.80 \\
\hline Status in the community & 2.80 & 2.72 & 2.89 & 2.79 \\
\hline Leadership opportunities & 2.68 & 2.67 & 2.70 & 2.68 \\
\hline Total income & 2.59 & 2.79 & 2.57 & 2.74 \\
\hline University salary & 2.44 & 2.60 & 2.51 & 2.57 \\
\hline & & & & \\
\hline Administration & 1.91 & 1.92 & 2.10 & 2.20 \\
\hline Poor job opportunities outside academia & 1.82 & 2.07 & 1.65 & 2.00 \\
\hline Sample Size & $989-999$ & $980-990$ & $258-262$ & $259-262$ \\
\hline
\end{tabular}

* higher scores mean higher importance, individual scores range from 1 = very unimportant to 5 = very important. Sample sizes vary slightly by factor due to occasional missing responses.

\section{Ideal Work Satisfaction}

In the survey, respondents were asked to rate 21 aspects of their work on their importance to their ideal work satisfaction. Each aspect was rated from 1 (Very Unimportant) to 5 (Very Important). Table 3 shows the mean scores in each response category.

TABLE 3. Ideal work satisfaction: importance of various factors in achieving ideal work satisfaction, by mean scores*

\begin{tabular}{|l|r|r|}
\hline Factors & non-accountants & accountants \\
\hline Control over your work & 4.60 & 4.49 \\
\hline Flexibility of working hours & 4.52 & 4.44 \\
\hline Ability to structure your day & 4.48 & 4.41 \\
\hline The intellectual atmosphere & 4.28 & 3.99 \\
\hline Time available for research & 4.19 & 3.95 \\
\hline Relationship with colleagues & 4.18 & 4.15 \\
\hline The variety of tasks you undertake & 4.12 & 4.05 \\
\hline Research & 4.09 & 3.81 \\
\hline Access to computing facilities & 3.94 & 3.91 \\
\hline Teaching & 3.93 & 4.08 \\
\hline Relations with your supervisor & 3.93 & 3.94 \\
\hline Opportunities to influence decisions & 3.85 & 3.78 \\
\hline Teaching resources & 3.80 & 3.90 \\
\hline Total income & 3.79 & 3.77 \\
\hline
\end{tabular}




\begin{tabular}{|l|r|r|}
\hline Administrative support & 3.76 & 3.76 \\
\hline Promotion opportunities & 3.76 & 3.76 \\
\hline The sense of community & 3.75 & 3.71 \\
\hline Staff development opportunities & 3.62 & 3.74 \\
\hline Office accommodation & 3.60 & 3.65 \\
\hline $\begin{array}{l}\text { Time available to assist students on a } \\
\text { one-to-one basis }\end{array}$ & 3.56 & 3.56 \\
\hline Administration & 2.19 & 2.35 \\
\hline number & $988-999$ & $260-262$ \\
\hline
\end{tabular}

* higher scores mean higher importance, individual scores range from 1 = very unimportant to 5 = very important. Sample sizes vary slightly by factor due to occasional missing responses.

Overall, there is good agreement across disciplines, genders and levels on the dimensions of the ideal work.

\section{Further analysis}

In the subsequent analysis, the question was: how can academics from a particular discipline, such as accounting, be distinguished from other business academics on the basis of their reasons for becoming an academic? Similar questions are posed in terms of the reasons for remaining an academic and their ideal requirements for work satisfaction.

Whilst this might initially seem a matter for discriminant analysis, such is not really the case here. This is because some, at least, of the classifying variables are clearly not Normally distributed-for example, most obviously the categorical variables such as gender and academic level—and because the covariance matrices are not known. Instead, logit and probit regressions were used. Both models were estimated as a check on the robustness of the results. The key concern is to determine which potentially explanatory variables are significant in predicting the academic discipline of the academics.

An initial logit analysis was conducted with the dependent variable being the respondents' main discipline area (10 levels) and explanatory variables the 13 factors rated for their importance in explaining why the respondent became an academic. Variables for gender, position level (Lecturer A to Professor level E), full or part time employment and length of time in academia were also incorporated into the model, to allow for the importance of the becoming factors to be discerned after adjusting for differences between the disciplines in the gender, position level, and so on of the respondents. This logit analysis was carried out with Quasi-Maximum Likelihood (QML) adjustment of the covariance matrix to allow for the 
possibility of model misspecification, and it showed that all potentially explanatory variables included in the model were significant ( $\mathrm{p}=0.000$ on Wald chi-squared tests).

However, inspection of the parameter estimates found that the significance of each explanatory variable was highly contingent on the "choice group"-that is, the disciplines being distinguished between in the model. Thus a variable might play an important role in the difference between accounting and law academics, but not between marketing and finance academics. Therefore the analysis needed to focus more closely on the differences between each discipline's academics and other business academics more generally-that is, a series of two-state dependent variables, rather than one dependent variable with a state for each discipline. This has the technical advantage of also simplifying the analysis and thus making it more robust (an intuition confirmed by the fact that the QML-adjusted and non-QML logit results differ for the one dependent variable, but do not differ except in minor detail for the series of two-state dependent variables).

In what follows, the $1 \%$ significance level ( $\mathrm{p} \leq 0.01$ ) was used as the cut-off to determine if a variable was reported as significant. This more stringent criterion than the common 5\% level was used because there were a large number of hypothesis tests conducted on each model—for example, the model considering the factors in becoming an academic had 24 parameters, each of which generated a hypothesis test of its significance-and it was important to reduce both the type I and II error rates in these circumstances.

In the analysis, the results from the logit models, the logit models with QML and the probit models were very similar, in every case finding the same variables significant with very similar $\mathrm{p}$ values. This adds to the confidence in the robustness of the results. Because of the close similarity of the results, only the probit results are reported in detail-the discussion and findings would be identical if either of the logit results were used instead

\section{Accounting Academics}

The dependent variable was whether or not the respondents identified accounting as their main discipline area. Table 4 shows that two of the factors in becoming an academic were of significance - Research and Autonomy, both with negative co-efficients. The dependent variable was coded with accountants having the higher value than non-accountants, so those rating Research and Autonomy as highly important factors in their becoming an academic were less likely to be accounting academics. Or, looked at another way, accountants were 
significantly less likely than other business academics to see research as very important in their becoming an academic, and thus more likely to give it lower ratings. This result is shown by the significant negative co-efficient for this variable in the logit model, and is after allowing for differences in gender, level, length of service, and so on. It can, however, be reported simplistically (without allowing for such differences) by observing that only $19 \%$ of accounting academics rated research as very important in their becoming an academic, whilst $37 \%$ of other business academics rated research as very important in that decision. Accounting academics were also much less likely to see Autonomy as a very important factor in their becoming an academic (35\% versus 50\%). Accounting and other business academics did not differ significantly on the factors not recorded in Table 4.

TABLE 4. Significant factors differentiating Accountants from other Business academics: (p values for t-test of significance of variable parameter)

\begin{tabular}{|c|c|c|c|}
\hline & Becoming & remaining & ideal \\
\hline & Research (0.000) - & Teaching (0.009) + & Intellectual atmosphere (0.003) - \\
\hline & Autonomy (0.002) - & $\begin{array}{l}\text { Administration (0.001) } \\
+\end{array}$ & \\
\hline Probit & $\underline{\text { model diagnostics }}$ & & \\
\hline$-2 \mathrm{LL}$ ratio & 98.9 & 79.2 & 92.3 \\
\hline df & 24 & 24 & 32 \\
\hline Chi-square p & 0.000 & 0.000 & 0.000 \\
\hline
\end{tabular}

\section{Discussion and Conclusions}

\section{Discipline differences - becoming an academic}

Further analysis of the data has shown that, at the level of discipline, there are some significant differences in the relative importance that business academics place on the factors identified (refer Table 4). For example, in deciding whether to enter academia, accountants are significantly less likely than other business academics to see research as very important. One possible explanation is that, whereas academic careers typically begin with a postgraduate research degree (Anderson et al. 2002, p 5) accountants tend to enter academia from industry/government, where they have had little exposure to research (Watty, Bellamy and Morley 1999, p. 250). Although the same might be said of other business academics, it is less likely—economists, for example, are much more likely to go directly into academia. 
The further analysis revealed that, although accountants place relatively less importance on research in deciding whether to enter academia, once there, they appear to undergo a value shift, coming to value research as highly as their business colleagues. Again there are several explanations. In an ethnographic study of accounting departments in four different types of universities, Watty, Bellamy and Morley (1999) found that some academics who engaged in research in order to meet institutional promotion criteria reported being surprised to find research intrinsically rewarding. In his 1999 study, reported earlier, McInnes found that 84\% of the business academics reported doing research/consultancy because they enjoyed it, it motivated and interested them. However, one must also admit the possibility that some academics change their behaviour without undergoing a change in values, if such behaviour carries rewards in the form of promotion, for example.

The present study also found that while accountants value autonomy, they value it less highly than do other business academics when entering academia. Perhaps the explanation relates to the nature of the accounting function and the inter-dependence of its tasks. An investigation by Holland (1973) into the link between personality and vocational choice revealed that the accounting environment fosters conformity and clerical competencies and explicit manipulation of data, records, or written material, and encourages people to see the world in conventional, stereotyped, constricted, simple and dependent ways. This finding suggests that, with the possible exception of those at senior levels in public practice or in auditing, where independence is required, autonomy is not as important as one might anticipate. Although Holland's theoretical propositions are somewhat dated and highly aggregative, they have been tested by a number of researchers (see, for example, Peters 1974; Smart 1976; Smart 1982) who have concluded that they represent a valid conceptual framework for investigating discipline-based differences in the attitudes and activities of academics.

A further finding of the present study was that, having once entered academia, accountants come to value autonomy as highly as their business counterparts. Perhaps they quickly learn to appreciate the relatively high degree of control and associated autonomy over their work that academia affords them, and are keen to retain it. 


\section{Discipline differences - remaining an academic and ideal}

In deciding whether to remain in academia, teaching and administration are significantly more important factors to accountants than to their colleagues-although administration is not important per se. With their background in 'conventional' environments, it is unsurprising that accountants may feel more comfortable with the administrative function. The answer to the question of why they value teaching so highly relative to other business academics is less simple, and may lie in the epistemological features of the discipline (Becher, 1989).

When considering 'ideal' requirements for work satisfaction, accounting academics are significantly less likely than other business academics to see intellectual atmosphere as very important.

\section{Impact on autonomy and flexibility}

Given the importance of autonomy and flexibility to business academics in general and accountants in particular, one is led to ask what effect the changes in higher education, discussed at the beginning of this article, have had on this aspect of the working lives of academics, and how they have reacted to the changes.

First, it is well-documented that workloads and task complexity have increased as a result of increasing student numbers, declining resources, additional compliance requirements, and so on - this is no less so for accountants than for other academics. In an Australian study (2000) published by the National Tertiary Education Union (NTEU) it was reported that $88.8 \%$ of academics claim to work more than 40 hours, $66.1 \%$ over 50 hours and $29 \%$ over 60 hours per week.

As these increases have occurred, a tension has developed between the core activities of teaching (a significantly important factor for accounting academics to remain in academia) and research, and additional work commitments, often compliance-driven. In relation to teaching, academics feel that there is insufficient time available to prepare materials, engage with students, develop technologies to enhance subjects, and so on. They are forced to make choices about where to focus their efforts. This has contributed to greater stress and diminishing job satisfaction. In a recent Australian study (Anderson et al. 2002) of over 2,000 academics, 64\% of respondents, male and female, regardless of university type, said that their job satisfaction had decreased; 82\% reported experiencing a higher level of stress. These findings are 
consistent with those of McInnes (1999), involving a sample of 2,609 academics (58.4 per cent response rate) drawn from 15 Australian universities across 5 states. The study aimed to identify trends in work roles and outlooks of academics in Australian universities since 1993. His findings suggested that there has been a drop in the general level of job satisfaction, with particularly low levels of satisfaction with job security, salary and key work conditions.

On the research front, the Anderson et al, 2002 study revealed that time available for scholarly writing-which lies at the core of research activity-has decreased. Almost 80\% of respondents reported a decrease, while over 93\% said that such time was either very or extremely important to them. There were no differences between academics from different types of universities in the perceived change. However, there were some differences according to how the respondents saw themselves-mainly teaching or mainly research. The researchers offered the explanation that committed researchers will make time to write, even at the expense of their teaching commitments, while committed teachers will not let anything interfere with their teaching priorities.

Finally, changes in higher education have seen the introduction by universities of academic performance review systems and academic promotion systems that reify government policies. For academics these systems, coupled with tightening time constraints, exacerbated by a compliance culture emanating from quality assurance systems, have resulted in a lessening of autonomy and flexibility; this is aside from any dispiriting effects resulting from 'goal posts' that are perceived to be-and may in fact be-perennially on the move. Accountants report being pushed in directions they do not want to go (Watty, Bellamy and Morley 1999). For example, serving on professional accounting association committees has always been a feature of the academic accounting profession, as has writing for professional journals; these are the mechanism through which academics contribute to debates and communicate new knowledge acquired from their research. The message from promotion criteria is that these activities are not valued and will not lead to career advancement. Again, this has taken away from accountants the control of their activities and their choices about what research to do. It has skewed professional activities in particular directions while further reducing the personal autonomy and flexibility of those whose performance is being assessed, sometimes for promotion purposes. 


\section{Reactions of Accounting Academics to Change}

How have accountants reacted to these institutional and externally-imposed changes? Have they been the 'passive recipients' reported by Jay and Parker (1995) and McMurty (1991) in their studies? While this is an empirical question not answered in the present study, some observations can be made.

First, as we saw earlier, accountants are viewed as having a 'conforming' persona (Holland, 1973). They are also pragmatic; this is confirmed in part by the finding from the present study that accountants are significantly less likely than their business colleagues to value intellectual atmosphere highly. Being conformists and pragmatists, they are likely to comply with requests from senior administrators to complete a process, activity or report, whether or not they see value in it. Accounting is largely about performance measurement and the production of accountability reports; these things are not anathema to accountants as they may be to academics in other disciplines, especially non-business ones. That is not to say that accountants do not complain (perhaps bitterly) about encroachments on their time, or about being pushed in directions they do not want to go, but rather that they are at least familiar with and possibly even comfortable with the concept of performance measurement and reporting.

A further point is that the changes may have impacted differentially on the working lives of accountants depending upon their orientation: teaching or research. It can be argued that the bureaucratization and politicization of quality assurance systems have affected the former more significantly than the latter.

There is, of course, the empirical question of how accountants have reacted to the pressure to engage in research and/or to increase their research efforts. Logic tells us that demands for behavioural change that conflicts with underlying discipline values is likely to be resisted. Thus, accountants seem likely to resist governmental and institutional demands for research, given their inclination towards teaching, the pragmatic nature of the discipline, the importance to them of maintaining links with the accounting profession, and the perceived devaluing of the teaching role that accompanies a heightened emphasis on research in reward systems and promotion criteria. While accountants might deny their lack of research orientation, much of the departmental output that passes for accounting research lies in the finance domain. 


\section{Remaining in Academia}

Policy-makers and university administrators would benefit from a clearer understanding of what academics factor into their career decisions about remaining in or exiting the university environment. This question has been answered in the present study: personal autonomy and flexibility, followed by teaching and research, are by far the most important factors in (becoming and) remaining an academic. The importance of autonomy has been confirmed in other studies. For example, Tack and Patitu (1992, cited in Johnsrud and Rosser 2002) found that US academics report their greatest sources of satisfaction as including the degree of autonomy they enjoy in their work.

Yet if the things that academics value have been slipping away, adversely affecting their job satisfaction and morale, and creating stress, why are they not leaving the halls of academia in droves? While morale has been found to be a primary factor in academics' intentions to leave their positions, their universities, and their profession (Johnsrud and Rosser 2002), there may be many reasons.

First, academics in general continue to enjoy a relatively high degree of autonomy relative to those employed outside the system, although the degree of autonomy varies with the type of institution; there is greater autonomy in the old and mid-period universities than in the new (McInnes 1999).

Second, business academics seem more contented than academics from other disciplines. McInnes (1999) found that of the 3 discipline groups surveyed-humanities/social science, engineering/architecture/agriculture and business - the business group: were generally more positive in their outlook and levels of job satisfaction; were more positive about their opportunities to pursue their own academic interests; were the least stressed; and worked significantly less hours than humanities academics, spending the least amount of time on administration and significantly less time on thesis supervision. On the issue of role overload, Winter et al. (2000) found that academics from health sciences and humanities/arts disciplines reported greater role overload than academics from business.

Third, although accountants, like other business academics may complain about increasing workloads and reduced autonomy/flexibility, they can still recall the demands of industry/government and the nature of accounting work-often repetitious and not as peopleorientated as academic work. Watty, Bellamy and Morley (1999) found that accounting 
academics develop an affinity with academic work that overrides their affinity with accounting and all that implies. They see their work as more in the nature of a calling than a job, and as being fundamentally different from that involved outside academia.

As a closing and general comment in relation to academics working in Australian HE, it is of note that in the study by McInnes (1999), 75\% of academics said they were motivated more by intrinsic interests in their work than by material (extrinsic) rewards, although the business group (66\%) was less motivated by intrinsic interests than the humanities/social sciences (81\%) and engineering/architecture/agriculture (72\%) groups. Recent years have seen a diminution in both extrinsic rewards (such as salary relativities) and intrinsic rewards (such as those derived from research, the challenge of teaching, peer support and personal autonomy). For example, research pressures, the requirement that staff produce and publish at unprecedented levels, have overtaken some of the excitement experienced by staff as emanating from the nature of the research process. Teaching is now evaluated by students, and academic performance is measured much more frequently and, sometimes, by external parties. The net effect of a reduction in both extrinsic and intrinsic rewards is that the latter may no longer be able to compensate for the serious erosion in the former, since they themselves have been affected.

The extent to which this erosion translates into less productive, less committed staff is difficult to gauge but should be a concern to policy-makers and university administrators. It is certainly a concern to the academics that represent around 40 per cent of all Australian university employees. 


\section{References}

Ackroyd, P. and Ackroyd, S. (1999) Problems of university governance in Britain: is more accountability the solution. The International Journal of Public Sector Management 12(3), 171-185.

Anderson, D., Johnson, R. and Saha, L. (2002) Changes in Academic Work: Implications for Universities of the Changing Age Distribution and Work Roles of Academic Staff, viewed October 10 2003, http://www.dest.gov.au/highered/otherpub/academic_work.htm

Becher, T. (1989) Academic Tribes and Territories: Intellectual Enquiry and the Cultures of Disciplines, Milton Keynes: The Society for Research into Higher Education \& Open University Press.

Watty, K., Bellamy, S. and Morley, C. (1999) Reshaping Higher Education: Cultural Explanations for the Responses of Academic Accountants to Enforced Change, Unpublished PhD thesis, RMIT University.

Watty, K., Bellamy, S. and Morley, C. (2003) Why business academics remain in Australian universities despite deteriorating working conditions and reduced job satisfaction: an intellectual puzzle. Journal of Higher Education Policy and Management, 25 (1), 13-27.

Coaldrake, P. and Stedman, L. (1998) On the Brink. Australia's Universities Confronting Their Future, University of Queensland Press, Qld, Australia.

Coy, D. and M. Pratt (1998) An insight into accountability and politics in universities: A case study. Accounting Auditing \& Accountability Journal 11(5), 540-561.

Dearlove, J. The academic labour process: from collegiality and professionalism to managerialism and proletarianisation? Higher Education Review, 30 (1), 56-75.

Erridge, A., Fee, R. and McIlroy, J. (1998) Public sector quality: Political project or legitimate goal. International Journal of Public Sector Management 11(5), 341-353.

Groot, G. (1999) Budgetary reforms in the non-profit sector: a comparative analysis of experiences in health care and higher education in the Netherlands Financial Accountability \& Management 15(3 \& 4), 353-376.

Holland, J. L. (1973) Making Vocational Choices, Englewood Cliffs, New Jersey: PrenticeHall.

Johnsrud, L.K. and Rosser, V.J. (2002) Faculty members' morale and their intention to leave, The Journal of Higher Education 73 (4), July/August, 518-542 
McInnes, C. (1999) The Work Roles of Academics in Australian Universities, 00/5 Evaluations and Investigations Programme, Higher Education division, June.

McMurty, J. (1991) Education and the market model. Journal of Philosophy and Education, 25 (2) 209-218

National Tertiary education Union (NTEU) (2000) Unhealthy Places of Learning, Working in Australian Universities, July.

Newton, J. (2000). "Feeding the beast or improving quality Academics' perceptions of quality assurance and quality monitoring, Quality in Higher Education 6(2), 153-163.

Peters, D. S. (1974) The Link is Inequitability, Research in Higher Education, 2, 57-64.

Smart, J. C. (1976) Duties Performed by Department Chairmen in Holland's Model Environments, Journal of Educational Psychology, 68, 194-204.

Smart, J. C. (1982) Faculty Teaching Goals: A Test of Holland's Theory, Journal of Educational Psychology, 74 (2), 180-188.

Trowler, P. R. (1998). Academics Responding to Change: New Higher Education Frameworks and Academic Cultures. Buckingham, UK., The Society for Research into Higher Education \& Open University Press.

Vidovich, L 1998, Quality as Accountability in Australian Higher Education of the 1990s: A Policy Trajectory, PhD thesis, Murdoch University, Perth.

Winter, R., Taylor, T. and Sarros, J. (2000), Trouble at Mill: Quality of Academic Worklife Issues Within a Comprehensive Australian University, Studies in Higher Education, 25(3), 279-294. 